\title{
Terminology Work in South Tyrol: New Approaches, New Termbase, New Contents
}

\author{
ELENA CHIOCCHETTI \\ Institute for Applied Linguistics, Eurac Research
}

\section{A B S T R AC T}

The paper gives an overview of the development of legal terminology work in South Tyrol. Working methods have evolved. Micro-comparison between the Italian and the German-speaking systems (Austria, Germany and Switzerland) has become a hallmark of our terminology work. The online system bistro (http://bistro.eurac.edu/) has also been renewed to accommodate changing user needs, e.g. providing advanced filtering and a feedback function. A policy of growing attention to target users has led us to include work on legal collocations. Further user requests concern domains like occupational health and safety. This implies treating relevant technical, medical and other scientific terminology. Doing this while remaining consistent with the methods applied to legal terminology poses a notable methodological challenge.

KEYWORDS: legal terminology, South Tyrol, micro-comparison, bistro, legal collocations, terminology user needs.

\section{ANOTACIJA}

Straipsnyje apžvelgiama teisès terminologijos darbo raida Pietų Tirolyje. Metodai yra patobulejęe. Išskirtinis atliekamų terminologijos srities darbų bruožas - itališkos ir vokiškos (naudojamos Austrijoje, Vokietijoje ir Šveicarijoje) kalbų sistemų lyginimas mikrolygmeniu. Atsižvelgiant į kintančius vartotojų poreikius, atnaujinta internetinè sistema bistro (http://bistro.eurac.edu/), pavyzdžiui, imta taikyti tobulesnè filtravimo ir grižtamojo ryšio funkcija. Vis daugiau dèmesio skiriant tiksliniams vartotojams, teko įtraukti teisès srities kolokacijas. Jau kyla vartotoju poreikių, susijusių su profesinės sveikatos ir saugos sritimis, vadinasi, reikia imtis ir techninès, medicininès bei kitų sričių mokslinès terminijos. Tai suderinti su teisès terminijai taikomais metodais didelis metodologinis iššūkis.

ESMINIAI ŽODŽıA: teisès terminija, Pietų Tirolis, lyginimas mikrolygmeniu, bistro, teisès srities kolokacijos, terminijos vartotoju poreikiai. 


\section{IN T RODUCTION}

By building upon and condensing previous research which illustrates the beginnings of terminology work in South Tyrol (Mayer 1997, 2000), the working methods adopted over a time span of about 25 years (Sandrini 1998; Maganzi Gioeni d’Angiò, Ralli 2010; Chiocchetti, Ralli 2016; Chiocchetti et al. 2017, 2019; Chiocchetti 2019) and the tools developed to disseminate results (Streiter et al. 2004; Ralli, Andreatta 2018), the paper aims to give an overview of the development of legal terminology work in South Tyrol since World War II.

South Tyrol (Südtirol - Alto Adige) is a multilingual province in Northern Italy, with about 525,000 inhabitants (ASTAT 2018: 9). Two thirds of the local population are speakers of a minority language: $70 \%$ have German as their first language while $4.5 \%$ are Ladin $^{1}$ native speakers (ASTAT 2018: 15). Today, both languages are officially recognised at local level, albeit to different degrees and in areas of different size.

German has co-official status in the entire Province (Presidential Decree No. 670/1972, Art. 99-100). The local public administration and the judiciary are obliged to offer their services in the language preferred by the citizen and to publish legislation and other official documents in both Italian and German. All public employees must prove knowledge of these two languages by passing an exam which has four different levels and consists of an oral and a written part. There are schools of all degrees with either Italian or German as a main medium of instruction and the other language taught as a second language. Place names are systematically bilingual (Palermo, Woelk 2011: 301; Alber, Palermo 2012: 291-293).

The Ladin language is officially recognised in the valleys of Gardena and Badia in South Tyrol. Ladin speakers are entitled to use their native tongue with the local public administration in the two valleys (e.g. the municipalities) and with provincial offices located outside the core area, provided that the latter mainly work in the interest of the Ladin community (e.g. the Ladin school board). Relevant legislation is made available also in the local Ladin variant or, at provincial level, alternately in one of

1 Ladin is an ancient Rhaeto-Romance language spoken in five valleys of the Dolomites that are part of three different provinces in Italy: Bolzano, Trento and Belluno. There are approximately 30,000 speakers in the entire area (Verra 2005: 115). About 20,000 live in South Tyrol (ASTAT 2018: 15), further 8,000 in Trentino (Lanzafame 2014:6) and the remaining few in the province of Belluno. In this paper we shall not deal with the history and language of the Ladin minority in detail. For more information consult, for example, Pescosta 2010. 
the two variants (Resolution of the Provincial Government No. 210/2003). Employees in the Ladin administration must prove the knowledge of all three official languages to the extent required for their specific position. In Ladin schools, Italian and German are equally used as a medium of instruction and alternated regularly. Ladin is also taught for a few hours per week (Verra 2005: 120). Place names in Gardena and Badia are trilingual in Ladin, German and Italian (Verra 2005: 118).

This brief overview illustrates a situation in which the two South Tyrolean minority communities enjoy a high degree of protection and many essential rights, definitely being the best safeguarded minorities in Italy (Alber, Palermo 2012: 290). Yet today's state is the result of decades of social, economic and political struggles, including even terrorist attacks (Forcher, Peterlini 2010: 338-362). South Tyrol had become part of Italy in 1919 after World War I. Despite all the promises made at the time by the King of Italy, the fascist regime that took power in 1922 systematically suppressed the German press and place names, fully Italianised the school system, the public administration and the judiciary, and basically forbade the use of German in public (Forcher, Peterlini 2010: 267273; Pescosta 2010: 366-368). Ladin was deliberately considered a dialect of Italian (Pescosta 2010: 383).

First minority rights were granted with the Paris Peace Treaties after World War II. However, the ensuing First Statute of Autonomy (Constitutional Law No. 5/1948), passed by the Italian Republic in 1948, left the South Tyrolean minorities largely unsatisfied. Some language rights and minority protection were established, such as German language press and schools and the possibility of teaching some Ladin at elementary school (Constitutional Law 5/1948, Art. 15, 87). Nevertheless, the public administration as well as the legislative and judicial powers remained largely Italian-speaking and basically inaccessible to members of the local minority communities (see Alcock 2001 for a more detailed historical account in English). In addition, the use of German for legislation, court proceedings and public administration remained a mere possibility (Constitutional Law 5/1948, Art. 85), thus scarcely put in practice (Alber, Palermo 2012: 293).

The situation changed radically in 1972, when the New Statute of Autonomy (Presidential Decree No. 670/1972) was approved by the Parliament in Rome. From that moment on, the South Tyrolean minorities received a growing number of rights and ample autonomy, including 
primary and secondary legislative powers in many domains of administration, which lead to the current asset and, not surprisingly, to an increased need for legal terminology. Due to space constraints, the following Sections will concentrate on the terminological development of German but not of Ladin in South Tyrol.

\section{THE BEGINNINGS OF TERMINOLOGY \\ DEVELOPMENT IN GERMAN}

Legal language poses a specific terminological challenge in South Tyrol. Designating Italian legal concepts in German requires particular efforts even today, for several reasons. First, in the past, German had never been used to express the Italian legal system and its concepts; therefore, no reference terminology was available (Coluccia 2000: 381). Second, for many decades the development of a German legal terminology for the above-mentioned purpose was hampered both by the fascist ban on the German language in South Tyrol and later, until the 1970s, by the marginalised status of the minority language in the judiciary system and in administration. Third, there are other nations in Europe where German is an official language at national or regional level (Ammon et al. 2016: XXXIX). However, due to the differences between legal systems and the resulting system-bound nature of legal concepts (de Groot 1999: 12), Austrian, German or Swiss terms, for example, cannot simply be borrowed to express the concepts of the Italian legal system (Alber, Palermo 2012: 300-310; Chiocchetti, Ralli 2016: 103-105). An evident case in point is the federal organisation of Austria, Germany and Switzerland that is reflected in their terminology. Such terms are largely inadequate to designate the more centralised Italian form of government.

Until half a century ago, the development of German legal terminology in South Tyrol was uncoordinated and not rarely ad-hoc. Mainly in the 1970s and 1980s, different teams of local academics, lawyers and judges working in specific domains joined efforts to translate the Italian legal codes pertaining to their respective fields of activity from Italian into German. The resulting parallel text editions of the Civil Code, Criminal Procedure Code, Insolvency Code, etc. were printed and distributed by a local publishing house (Zanon 2001: 178). In the aftermath of the New Statute of Autonomy and due to the new status of German as coofficial language, many other texts, such as laws and administrative documents of all kinds, were translated into German by public officials, clerks 
and professional translators for both internal and public use. Regrettably, all these efforts were not directed by a central office and lacked the necessary strategic language and terminology planning. Translations were often drafted on a needs basis or left to the (private) initiative of offices, clerks, associations, etc. concerned with specific topics (Mayer 1997: 128; Palermo, Pföstl 1997: 53; Woelk 2000: 213; Chiocchetti et al. 2017: 258). As a consequence, the same concepts often ended up being designated by different terms in German (Mayer 1997: 128-129; Sandrini 1998: 399400; Zanon 2001: 178; Chiocchetti et al. 2013: 261; Chiocchetti, Ralli 2016: 105; Chiocchetti 2019: 178), creating concurring designations, confusion and terminological uncertainty. For example, beni ereditari (property belonging to a deceased person's estate) was rendered Erbschaftsgüter in the translated Civil Code and Nachlassgüter or Verlassenschaftsgüter in the Civil Procedure Code.

When the New Statute of Autonomy was approved in 1972, it was soon realized that the implementation of the new language provisions needed to be based on consistent, complete and univocal legal terminology. It took over a decade of further uncontrolled development before a dedicated Terminology Commission was established by Presidential Decree 574/1988. The Terminology Commission was set up in 1991 and consisted of six experts (bilingual judges, lawyers and translators). Its mandate was to officially validate legally binding couples of Italian and German terms in the main subdomains of law (e.g. civil law, criminal law, procedure law, administrative law, etc.). The Commissioners' aim was to develop a consistent set of well-researched German terms designating the most important legal concepts of the Italian legal system, which had to be used by the South Tyrolean legislature, judiciary and administration. These terms were intended as one-to-one correspondents to the legal terminology in Italian and as a means of fostering legal certainty and reducing terminological variation in South Tyrolean German (Alber, Palermo 2012: 97-298; Chiocchetti et al. 2013: 266-268; 2019: 176-177; Chiocchetti, Ralli 2016: 105-106).

The Italian and German term couples were published progressively in the local Official Gazette in form of parallel lists. From the moment of their publication, the officially standardised terminology became legally binding in South Tyrol. In about 20 years of activity, the Terminology Commission managed to standardise approximately 7,400 couples of terms. The first list was published in 1994, the last in 2012. In addition, further 
terminology was already available in the parallel text editions of the main Italian legal codes. The terminology contained in these translations was batch standardised, bringing the amount of officially validated terms in South Tyrol to an estimated number of 15,000 to 20,000 (Chiocchetti et al. 2017: 265; 2019: 187).

The Commissioners were supported in their standardisation work by a team of terminologists and legal experts at Eurac Research (http://www. eurac.edu/linguistics) taking care of the preliminary research activities. The interdisciplinary team started working with a systematic and domainoriented approach by delimiting every subdomain under analysis and acquiring relevant source material. From there they extracted, selected and ordered the most important terms within the key subdomains of the Italian legal system (e.g. criminal law, family law, labour law) in Italian. Then they collected existing German designations for these national legal concepts in South Tyrolean texts. Definitions and contexts of use from relevant and authoritative books or normative texts were added, together with information on their sources (Mayer 1997: 126; Chiocchetti et al. 2019: 177-178). These fully-fledged terminological entries elaborated according to terminological principles and methods (Arntz et al. 2014: 211219) served as a basis for the decisions of the Terminology Commission that officially validated one South Tyrolean designation for every legal concept treated. In this way standardisation work contributed greatly to suppressing old impromptu or incorrect terms and to reducing terminological variation in South Tyrolean legal German. For example, the standardised term Erbschaftsgüter is now the only designation used to render beni ereditari in local legislation. The systematic approach allowed to create a stock of coherent German terminology for the most important domains of activity of the local legislature, jurisdiction and administration.

\section{NEW APPROACHES}

The first change in working approach concerns legal comparison. This method allows to compare different legal systems against each other to detect similarities and differences. The comparison can involve entire legal families and legal systems with regard to their general methods and approaches to legal issues, legislative practice, legal interpretation, jurisprudence, etc. (macro-comparison). It can also concern specific concepts or problems. In the latter case the method is termed micro-comparison (Zweigert, Kötz 1996: 4-5; Pommer 2006: 84-85) and becomes relevant 
for terminology work in the domain of law (Sandrini 1996: 160-166; Mayer 1997: 126-127; de Groot 2002: 222; Chiocchetti 2019: 180-182). Micro-comparison allows to understand whether two designations belonging to different legal systems refer to the same legal concept or not, i.e. to check whether the relevant characteristics of the given concepts coincide or to detect important conceptual discrepancies (see e.g. Chiocchetti, Ralli 2016: 107-110 for examples). In relation to terminology work in South Tyrol, applying micro-comparison means looking for legal concepts in Austria, Germany and Switzerland that are conceptually equivalent to the Italian legal concepts under analysis and which have a similar function within their respective legal systems (Mayer 2000: 299; Chiocchetti, Ralli 2016: 106-111).

At the onset of terminological activities in South Tyrol, it soon became clear that terminology work was not possible without casting a look across the border. South Tyrol has only over 300,000 speakers of German (ASTAT 2018: 9), while there are almost 100,000,000 other native speakers in Europe, mainly residing in Austria, Germany and Switzerland (Biere 2017: 22). In addition, South Tyrol has always maintained thriving social, cultural, commercial and political contacts with these countries (Woelk 2000: 213-214). Therefore, to avoid an excessive regionalisation of South Tyrolean German and to foster transnational communication with the other German-speaking areas (Sandrini 1998: 408), considering the terminology used in the neighbouring countries would have been an advantage. Also, on very practical terms, the Terminology Commission could adopt two strategies to fill any terminological gaps: either produce neologisms or borrow foreign German designations used for equivalent concepts. This implied introducing microcomparison for concepts with non-existing or inadequate designations in South Tyrolean German (Mayer 1997: 129; 2000: 299). At first, this rather "laborious and time-consuming method" (Mayer 2000: 297) was applied sporadically to fill terminological gaps or propose better fitting designations. At the beginning of the new millennium, however, an EU-financing allowed to extend the method to a growing number of concepts. Over the years, legal comparison became a fundamental practice to ensure a high degree of terminological quality in South Tyrol (Mayer 2000: 297), primarily by reducing impromptu and often literal translations from Italian and inadequate German designations. Today, legal comparison between the Italian legal system and the neighbouring German-speaking systems it is the hallmark of terminology work at Eurac Research (Chiocchetti et al. 2019: 178). 
The second change in working approach, about a decade later, was a shift from a systematic and basically standardisation-oriented to a more descriptive approach, which also allows for ad-hoc and text-oriented terminology work. This transition became necessary when the activities of the Terminology Commission were discontinued in 2012 due to several reasons. All the Commissioners were employed full-time in other positions, so that they could work on terminology issues only occasionally and standardisation work did not proceed at high speed. In addition, only three out of six Commissioners were native German speakers. These three had a higher workload than their Italian-speaking colleagues, especially when neology was necessary. The formal procedure for standardisation further hampered activities, because the lists validated by the Terminology Commission needed to be approved by both the local government and the local representative of the central government before being published in the Official Gazette. This meant a systematic delay of six months. The lack of time and the lengthy procedure in the end made it difficult to keep up with new legislation, the designation of new concepts and the necessary revisions in case of legal reforms. Indeed, it happened that previously standardised terms became outdated quite soon. Finally, if we consider that the terminological needs became urgent in 1972 when the New Statute of Autonomy was passed and that the first standardisation results were published in 1994, a delay of over 20 years becomes evident. In the meantime, terminological development kept happening in an uncoordinated and unplanned way, making subsequent standardisation even more challenging (Chiocchetti et al. 2017: 262-263).

Despite all these obstacles, the standardisation efforts have provided a fair amount of established terminology in several subdomains of law and most importantly - drawn attention to the quality of language, translation and terminology as well as to the existing terminological repositories. Not all standardised terms were accepted by the users, terminological variation still exists and there remain several domains which would need some systematic terminology work (e.g. tax law). Such systematic work is still done when new domains are explored, but a notable share of the terminological activities at Eurac Research today are text-related (for example, when new legislation is passed on important topics) and ad-hoc (for example, when new concepts become relevant or specific requests are posted). In addition, the existing stock of terminology is regularly checked 
and, if necessary, updated. Today, maintenance and updating are essential steps to preserve the quality and reliability of any terminological resource for its end users (Drewer, Schmitz 2017: 37; Zanola 2018: 77).

Standardisation work was always based on essentially descriptive terminological entries. With the last normative step being abandoned, the descriptive approach remained in place. In addition, since it is now easier to disseminate terminology widely (e.g. via the Internet) and the aim of terminology work today is not just developing South Tyrolean legal language anymore, but facilitating and fostering transnational communication, standardisation is not needed with the same urgency as before. When there are still doubts on which term, among a set of two or more concurring ones, should be used in South Tyrol, the terminologists at Eurac Research consult with the Office for Language Issues, which is responsible for the translation and revision of local legislation, and with domain experts, so that a joint recommendation may be given. However, this recommendation is in no way legally binding and the users remain free to choose based on the information made available in the terminological entries.

The third and last change in working approach concerns cooperation with end-users. In the 1990s, the most urgent domains had been selected on a needs basis, favouring the subdomains that were more relevant for the South Tyrolean public administration and the judiciary, while essentially leaving out some others such as, for example, maritime law and church law. In the last three decades the local government has acquired additional primary and secondary legislative powers and some subdomains have gained relevance, for example occupational health and safety. Consequently, the current approach to terminology work is very focused on the needs expressed by the end users. For example, the request for terminology work in the domain of occupational health and safety was voiced by the responsible offices within the local administration. Terminology work on living wills was triggered by a new law approved in 2017 in Italy. Several ad-hoc requests were posted by other local public or private organisations, e.g. the Court of Auditors, the Customs Agency and private users or associations. Such requests are analysed, answered and the results are made available to the general public.

Paying greater attention to the real needs of users allows the terminology work at Eurac Research to be focused on current topics and, at the same time, to disseminate work more easily among specific professional communities. Working on present-day legislation and debated topics as 
soon as possible also helps directing the language choice of text drafters in the local media and administration, thus reducing the spawning of impromptu translations and terminological variation. For example, making comparative terminology work on the terminology used in the debate on same-sex civil partnerships available very soon helped eliminate literal translations such as zivile Union for the Italian term unione civile and disseminated the equivalent eingetragene Lebenspartnerschaft. The latter is the term used in Germany, whose legislation served as a model for the Italian one (Deputati PD 2016: 1). The Swiss and Austrian term eingetragene Partnerschaft is very similar and further supports the choice of an established foreign equivalent rather than a literal translation that would be understood only by South Tyroleans.

\section{NEW TERMBASE}

To be effective and valuable, terminology work needs to be disseminated and made available to its end users (Arntz et al. 2014: 251; Drewer, Schmitz 2017: 30). The bilingual word lists of standardised terms published in the Official Gazette were not widely accessible. Furthermore, the full terminological entries contained additional precious information like definitions, contexts of use and notes that were also worth sharing. For this reason and thanks to the favourable technological development, since 2002, all the terminological entries produced at Eurac Research have been published in full and made freely available online through the Information System for Legal Terminology bistro (http://bistro.eurac.edu/).

bistro's aim is to foster communication and mutual understanding between people and organisations from different legal systems, with a focus on Austria, Italy, Germany and Switzerland. The relevant supranational levels of EU law and international law are partly included, too. With a more local focus, bistro also intends to support and promote the development and harmonisation of legal terminology in South Tyrolean German. Its contents mainly relate to administrative, civil, commercial, company, criminal, family and (civil and criminal) procedural law. Occupational health and safety is another well-represented legal subdomain today. bistro's target groups are both professionals, i.e. legal experts, legal text drafters and translators, as well as students of law, linguistics, translation and related disciplines. bistro contains terminology in Italian, German and - to a much smaller extent - Ladin. Its unique feature is that German 
terminology is clearly distinguished according to the legal system it belongs to. Also for Ladin terms there is information on which of the two local variants they belong to (Ralli, Andreatta 2018: 8).

Computer linguists at Eurac Research started developing bistro in 2001 to allow a quick and generalised access to terminological and standardisation-oriented information in South Tyrol. Entries were elaborated within a commercial terminology management system (TMS) and then published via bistro. At the time, bistro's architecture was a relational database: it was modular and data visualisation was dynamic. An XML-file from the TMS was imported and the content of each entry (e.g. terms, definitions, grammatical information, source information, etc.) was stored separately in different SQL tables. These were connected through bidirectional graphs, so that all information could be retrieved during user searches. Data visualisation was organised in different views, dynamically combining data and using stylesheets (XSLT, CSS) (Streiter et al. 2004: 204, 213). Nevertheless, information in terminological entries was always shown in the same sequence and it was not possible to order the contents by language, for example, or by search term (Chiocchetti et al. 2019: 186). Next to providing access to terminology, the former bistro also offered a bilingual corpus of legal texts called CATEx (Gamper, Dongilli 1999) as well as basic term extraction and term recognition tools.

Over the years, and partly due to further technological development, the first version of bistro became slow and obsolete. It was not particularly user-friendly, the content of the updated terminological entries started differing from the aging CATEx corpus of legal texts and the search functions were limited. Updating the relational database became more and more complex and time-consuming as well as error-prone. For these and other reasons, thanks to a financing by the Autonomous Province of Bolzano, in 2013 a team of terminologists and IT experts began to rethink, restyle and reprogramme bistro, making the system more flexible, user-friendly and interactive (see Ralli, Andreatta 2018 for a detailed account over all is functions and features).

Targeting the same user groups but focusing more on international cooperation and communication, the new bistro offers first a basic overview of all the terms designating the same concept and quick access to the full terminological entry, if users wants to receive more information. It is also possible to choose between a simple and advanced search mode. The 
latter has filter functions for every language or variant, legal system and specific legal subdomain contained in the terminological entries (Ralli, Andreatta 2018: 21-22). This means, for example, that users translating a text from Italian into German for Austrian readers may decide to apply a filter and so remove information concerning the other German-speaking legal systems and the Ladin language. Users may also choose to expand or collapse contexts or to access full bibliographic information for every source (Ralli, Andreatta 2018: 29). From the point of view of data maintenance, better and quicker import functions were provided for (Ralli, Andreatta 2018: 38-39). A feedback button allows users to comment on existing entries, suggest changes or propose new terms to be added (Ralli, Andreatta 2018: 30). Finally, since they were often leading users astray and not on a par with recent technologies, outdated tools and contents like the CATEx and the term extraction tool were removed.

Today (July 2019) bistro contains about 12,500 bilingual terminological entries, a small amount of which are trilingual and also contain Ladin terms. Many are legal comparative entries, i.e. they collect not only the Italian and German (and sometimes Ladin) designations for Italian legal concepts, but also the German terms for equivalent foreign concepts from Austria, Germany and Switzerland. bistro has become a flexible, reliable and intuitive system, both for the terminologists, who update its contents by regularly uploading an export from the commercial TMS, and for its target user groups (Zanola 2018: 77-78). This is shown by the growing number of accesses since 2016: in the first 12 months accessed doubled (from 12,000 to over 26,000), in the following year they reached almost three times the initial number $(36,000)$ (Chiocchetti et al. 2019: 189). Inputs and questions received through the feedback form also show that there is increasing interest in bistro outside South Tyrol (Chiocchetti et al. 2019: 185).

\section{NEW CONTENTS}

As illustrated in the previous sections, past efforts have provided bistro users with a notable stock of reliable legal terminology, even though several domains remain to be completed, updated or treated. Also, we have seen that paying greater attention to the needs of end users and providing them with a dedicated feedback function (Drewer, Schmitz 2017: 31) in bistro has partly changed the approach to terminology work. 
Another consequence of this greater attention to users is that, about a decade ago, Eurac Research started elaborating legal collocations ${ }^{2}$. (Specialised) collocations represent frequent pitfalls both for unexperienced but also for advanced language mediators and foreign or second language users (Holderbaum, Prien 2004: 451; Forget 2014: 245; Grass 2014: 109; Lerat 2014:98). Adding them to bistro meant inserting a semasiological (i.e. wordoriented) section into relevant entries which are elaborated following an onomasiological (i.e. concept-oriented) principle (Maganzi, Ralli 2010: 100). The collocations are therefore filed under the main headword so far (e.g. adempiere un contratto, i.e. to fulfil a contract, is stored under the headword contratto) and are visible only when accessing the full terminological entry (Ralli, Andreatta 2018: 20). The small collection of bilingual collocations is particularly appreciated by translators (Grass 2014: 108-109) and by people who are not used to drafting legal texts or need to do so in their second language (Maganzi, Ralli 2010: 106). Currently bistro contains almost 1,500 collocations in Italian and over 1,800 in German. Following the approach used for the terminology itself, collocations are also attributed to one or more legal systems. This is due to the fact that collocations are systembound, too. For example, eine Frist beifügen or beisetzen, i.e. to set a deadline, may be used in South Tyrol, but not in other legal systems, which prefer eine Frist ansetzen. Similarly, als Erbe berufen, i.e. to nominate someone heir, is used frequently in the German legal system, while als Erbe einsetzen is more common in Austria and Switzerland.

The closer cooperation with (potential) end users brought requests for terminology work in domains that go beyond the core content of bistro, i.e. the legal domain. For example, when dealing with occupational health and safety (OHS) it is necessary to decide how to treat technical, medical and other scientific terminology, which is a fundamental part of OHS, but not strictly legal. For example, "ladders", "hoists", "vibration", "radiation" or specific diseases like "asbestosis" or "burnout" are key terms in OHS, even though one would probably not expect to find them in a

2 For the purposes of bistro, the team of terminologists at Eurac Research adopted the definition by U1rich Heid and Rufus H. Gows, who understand collocations very widely as "lexically and/or pragmatically constrained recurrent occurrences of at least two lexical items which are in a direct syntactic relation with each other" (Heid, Gows 2006: 980). This includes groups composed of N + Adj, Adj + Adv, $\mathrm{V}+\mathrm{Adv}, \mathrm{V}+\mathrm{N}_{\mathrm{obj}}, \mathrm{N}_{\text {subj }}+\mathrm{V}, \mathrm{N}+\mathrm{N}_{\text {gen }}$, etc. Since some of these are typical structures of multiword expressions representing legal concepts, e.g. $\mathrm{N}+$ Adj or $\mathrm{N}+\mathrm{N}_{\text {gen }}$, which are treated onomasiologically, the collocations in bistro are predominantly V + N groups (Maganzi, Ralli 2010: 100-102). 
legal termbase. In addition, many of these terms have scientific definitions which do not change across legal systems, and therefore, legal comparison is not necessary.

Legislation affects all aspects of life. For this reason, it is not uncommon that terms originally belonging to other domains become relevant from a legal point of view. For example, in family law regulations on "artificial insemination" are important; some practices may be allowed or forbidden (e.g. "donor insemination" was forbidden for over a decade in Italy). Therefore, bistro has always contained a small amount of terminology originally pertaining to other domains but used in legislation, sometimes even with a specific legal definition different from the definition in the source domain. Working on OHS means facing a wealth of such terms, so that a shared decision on when and how to add them to the termbase and how to elaborate the entries becomes necessary. As a general rule, we decided to store legal definitions and contexts of use from legal texts whenever possible for every legal system considered, so as to treat these terms consistently with the main set of legal terminology. Key OHS terms are extracted only from relevant legal or administrative texts to avoid going into excessive technical detail. The same rules are applied to the German part of entries for every legal system considered.

Despite the fear of flooding bistro with technical and medical terminology, the requests to add new domains have been accepted, as in the case of OHS, or are being considered, as in the case of social housing. This implies working also on terminology that is not strictly legal and leads to new approaches, working methods and user groups. In future, bistro may open up to many other domains and become a more generalised resource for Italian and German.

\section{CONCLUSIONS}

The present paper gives an overview of the evolution of legal terminology work for German in South Tyrol since World War II. The methodological approaches to terminology work have changed to enhance language quality and adapt to new situations. Over the years, the method of microcomparison between the Italian and the German-speaking systems has become a hallmark of terminology work at Eurac Research in Bolzano. For the Italian legal concepts analysed by an interdisciplinary team of terminologists and legal experts, information is given on the terms used in South 
Tyrolean German but also on equivalent concepts existing in other Germanspeaking countries (Austria, Germany and Switzerland). A unique feature of terminology work at Eurac Research is that every term is clearly assigned to one or more specific legal systems, thus fully acknowledging the systembound nature of legal terminology. With a view to developing South Tyrolean German legal terminology, this approach allows to avoid an excessive regionalisation of the local legal and administrative language, because whenever acceptable foreign equivalents are available, the respective terms can be adopted and used in South Tyrol. With a view to international cooperation and trade, it greatly fosters transnational communication between Italy and the German-speaking countries.

The online system used to disseminate the results of this work, bistro, has also been completely renewed to accommodate the needs of terminologists and target users. This was done on the one hand with the aim of keeping the pace with technological development. On the other hand, it meant to provide an intuitive and easy-to-use terminology lookup tool that includes advanced filter functions, expandable contexts, access to full bibliographical information and a feedback function. The latter is part of a new policy that fosters growing interaction with target users, be they single persons or entire offices and organisations. To facilitate the production process by text drafters and translators and provide precious additional linguistic information, several terminological entries in bistro contain a section dedicated to legal collocations. While the terminological entries are elaborated with a concept-oriented approach, collocations follow a word-oriented approach and can be found at the end of the entry treating the relevant headword. Finally, on the request of its users, bistro is slowly opening up to new domains like occupational health and safety or social housing. Such domains include a notable amount of relevant technical, medical and other scientific terminology. Treating such terms while still remaining consistent with the methods used for legal terminology poses a notable methodological challenge, which we have tried to solve with a pragmatic approach.

The lesson we have learnt by implementing all these innovations and evolutions is that terminology work needs to regularly adapt to legal, technological and societal changes to remain valuable. Methods, tools and contents must cater for the changing needs of target users and foster terminology dissemination. 


\section{LEGAL REFERENCES}

Constitutional Law No. 5/1948 (First Statute of Autonomy). - Legge costituzionale del 26 febbraio 1948, n. 5 "Statuto speciale per il Trentino - Alto Adige". Available at: http://www.consiglio-bz.org/download/1.Statuto-di-Autonomia-1948.pdf [accessed 19.08.2019].

Presidential Decree No. 670/1972 (New Statute of Autonomy). - Decreto del Presidente della Repubblica del 31 agosto 1972, n. 670 "Approvazione del testo unico delle leggi costituzionali concernenti lo Statuto speciale per il Trentino - Alto Adige”. Available at: http://lexbrowser.provinz.bz.it/doc/it/dpr-1972-670/decreto_ del_presidente_della_repubblica_31_agosto_1972_n_670.aspx [accessed 19.08.2019].

Presidential Decree No. 574/1988. - Decreto del Presidente della Repubblica del 15 luglio 1988, n. 574 "Norme di attuazione dello Statuto speciale per la regione Trentino - Alto Adige in materia di uso della lingua tedesca e della lingua ladina nei rapporti con la pubblica amministrazione e nei procedimenti giudiziari". Available at: http://lexbrowser.provinz.bz.it/doc/it/dpr-1988-574/decreto_del_presidente_della_repubblica_15_ luglio_1988_n_574.aspx [accessed 19.08.2019].

Resolution No. 210/2003 by the Provincial Government of South Tyrol. - Delibera della Giunta Provinciale del 27 gennaio 2003, n. 210 "Utilizzo della lingua ladina da parte degli enti pubblici e negli atti normativi". Available at: http://lexbrowser.provinz.bz.it/doc/20141121/it/1571/delibera_n_210_del_27_01_2003.aspx [accessed 19.08.2019].

\section{REFERENCES}

Alber E., Palermo F. 2012: Creating, Studying and Experimenting with Bilingual Law in South Tyrol: Lost in Interpretation? - Bilingual Higher Education in the Legal Context. Group Rights, State Policies and Globalisation. X. Arzoz (ed.), Leiden: Nijhoff, 287-309.

Alcock A. 2001: The South Tyrol Autonomy. A Short Introduction, Londonderry / Bolzano: Autonomous Province of Bolzano / Bozen.

Ammon U., Bickel H., Lenz A. N. (eds.) 2014: Variantenwörterbuch des Deutschen. Die Standardsprache in Österreich, der Schweiz, Deutschland, Liechtenstein, Luxemburg, Ostbelgien und Südtirol sowie Rumänien, Namibia und Mennonitensiedlungen, Berlin: De Gruyter.

Arntz R., Picht H., Schmitz K.-D. 2014: Einführung in die Terminologiearbeit. $7^{\text {th }}$ ed., Hildesheim: Olms.

ASTAT - Landesinstitut für Statistik / Istituto provinciale di statistica 2018: Südtirol in Zahlen/Alto Adige in cifre, Bolzano / Bozen: ASTAT.

Biere B. U. 2017: Ein Europa - Viele Sprachen: Mehrsprachigkeit in Europa, Brey: Mykum.

bistro - Information System for Legal Terminology, Bolzano: Institute for Applied Linguistics of Eurac Research. Available at: http://bistro.eurac.edu/ [accessed 19.08.2019].

Chiocchetti E. 2019: Legal Comparison in Terminology Work: Developing the South Tyrolean German Legal Language. - Diszciplínák találkozása: nyelvi közvetítés a XXI. Században. S. Szoták (ed.), Budapest: OFFI, 175-185.

Chiocchetti E., Ralli N. 2016: Ein Begriff, zwei Sprachen, unterschiedliche (Rechts)Kulturen. - Terminologie und Kultur. Akten des Symposions, Mannheim, 3.-5. März. P. Drewer, F. Mayer, K.-D. Schmitz (eds.), Munich et al.: Deutscher Terminologie-Tag e.V., 103-112.

Chiocchetti E., Kranebitter K., Ralli N., Stanizzi I. 2019: 25 Jahre Bozner Methode: Terminologiearbeit in Südtirol. - Terminologie: Epochen, Schwerpunkte, Umsetzungen. Zum 25-jährigen Bestehen des Rats für deutschsprachige Terminologie. P. Drewer, D. Pulitano (eds.), Berlin: Springer Vieweg, 175-191.

Chiocchetti E., Kranebitter K., Ralli N., Stanizzi I. 2013: Deutsch ist nicht gleich Deutsch. Eine terminologische Analyse zu den Besonderheiten der deutschen Rechtssprache in Südtirol. - Diatopische Variation in der deutschen Rechtssprache. M. M. Brambilla, J. Gerdes, C. Messina (eds.), Berlin: Frank, Timme, 253-285.

Chiocchetti E., Ralli N., Stanizzi I. 2017: From DIY Translations to Official Standardization and Back Again? 50 Years of Experience with Italian and German Legal Terminology Work in South Tyrol. Terminological Approaches in the European Context. P. Faini (ed.), Cambridge: Cambridge Scholars, 254-270.

Coluccia S. 2000: Il linguaggio giuridico in Alto Adige. - Heimat. Identità regionali nel processo storico. Antonio Pasinato (ed.), Rome: Donzelli, 379-388.

De Groot G.-R. 1999: Das Übersetzen juristischer Terminologie. - Recht und Übersetzen. G.-R. de Groot, R. Schulze (eds.), Baden Baden: Nomos, 11-46. 
De Groot G.-R. 2002: Rechtsvergleichung als Kerntätigkeit bei der Übersetzung juristischer Terminologie. Sprache und Recht. U. Haß-Zumkehr (ed.), Berlin: De Gruyter, 222-239.

Deputati PD 2016: La legge sulle unioni civili. Dossier n. 145. Available at: http://www.deputatipd.it/files/documenti/145_La_legge_sulle_unioni_civili_(1).pdf [accessed 19.08.2019].

Drewer P., Schmitz K.-D. 2017: Terminologiemanagement. Grundlagen - Methoden - Werkzeuge, Berlin: Springer Vieweg.

Eurac Research - Institute for Applied Linguistics. Available at: http://www.eurac.edu/linguistics [accessed 19.08.2019].

Forcher M., Peterlini H. K. 2010: Südtirol in Geschichte und Gegenwart, Innsbruck: Haymon.

Forget P. 2014: La phraséologie chez les jurilexicographes: les exemples linguistiques dans da deuxième edition du Dictionnaire de droit privé et lexiques bilingues. - Legal Lexicography. A Comparative Perspective. M. M. Aodha (ed.), Abingdon: Routledge, 223-264.

Gamper J., Dongilli P. 1999: Primary data encoding of a bilingual corpus. - Sammelband der Jahrestagung der GLDV 99. J. Gippert (Hrsg.), Prague: Enigma, 323-331.

Grass T. 2014: Principes terminologiques pour la constitution d'une base de données pour la traduction juridique. - Legal Lexicography. A Comparative Perspective. M. M. Aodha (ed.), Abingdon: Routledge, 103-114.

Heid U., Gows R. H. 2006: A Model for a Multifunctional Dictionary of Collocations. - Proceedings of the XII EURALEX International Congress (Turin, 6-9 September 2006), Vol. 1. E. Corino, C. Marello,

C. Onesti (eds.), Alessandria: Dell'Orso, 979-988.

Holderbaum A., Prien M. 2004: Kollokationen im Web: Zur Herleitung einer zweisprachig ausgearbeiteten Kollokationsdatenbank. - AREAS 26, 451-472. Available at: http://areas.iued.uni-heidelberg.de/artikel/ Band26.pdf [accessed 19.08.2019].

Lanzafame F. 2014: Rilevazione sulla consistenza e la dislocazione territoriale degli appartenenti alle popolazioni di lingua ladina, mòchena e cimbra $\left(15^{\circ}\right.$ Censimento generale della popolazione e delle abitazioni - dati definitivi), Trento: Servizio statistica della Provincia Autonoma di Trento. Available at: http://www.statistica. provincia.tn.it/binary/pat_statistica_new/popolazione/RilevazionePopolazioniLadinaMochenaCimbra.1394031752.pdf [accessed 19.08.2019].

Lerat P. 2014: Pour des dictionnaires juridiques multilingues du citoyen de l'union européenne. - Legal Lexicography. A Comparative Perspective. M. M. Aodha (ed.), Abingdon: Routledge, 89-102.

Maganzi Gioeni D’Angiò F., Ralli N. 2010: Data modeling delle collocazioni: fra terminologia e lessicografia. - Fachsprachen in der weltweiten Kommunikation / Specialized Language in Global Communication. Akten des XVI Europäischen Fachsprachensymposiums, Hamburg 2007 / Proceedings of the XVIth European Symposium on Language for Special Purposes (LSP), Hamburg (Germany) 2007. W. von Hahn, C. Vertan (eds.), Frankfurt a. M.: Peter Lang, 99-106.

Mayer F. 1997: Terminologiearbeit in Südtirol. - Terminologie et Traduction. W. Osterheld (ed.), Luxembourg: Office des publications officielles, 124-137.

Mayer F. 2000: Terminographie im Recht: Probleme und Grenzen der Bozner Methode. - Rechtslinguistik des Deutschen und Italienischen. D. Veronesi (ed.), Padova: UNIPRESS, 295-306.

Palermo F., Pföstl E. M. 1997: Normazione linguistica e tutela minoritaria / Minderheitenschutz durch Sprachnormierung, Bolzano / Bozen: Accademia Europea di Bolzano / Europäische Akademie Bozen.

Palermo F., Woelk J. 2011: Diritto costituzionale comparato dei gruppi e delle minoranze, 2nd ed. Padova: CEDAM.

Pescosta W. 2010: Storia dei ladini delle Dolomiti, San Martin de Tor: Istitut Ladin Micurà de Rü.

Pommer S. 2006: Rechtsübersetzung und Rechtsvergleichung, Frankfurt a. M.: Peter Lang.

Ralli N., Andreatta N. 2018: bistro - ein Tool für mehrsprachige Rechtsterminologie. - trans-kom. Zeitschrift für Translationswissenschaft und Fachkommunikation 11, 1, 7-44.

Sandrini P. 1996: Terminologiearbeit im Recht. Deskriptiver begriffsorientierter Ansatz vom Standpunkt des Übersetzers, Vienna: Termnet.

Sandrini P. 1998: Italienisches Recht in deutscher Sprache - Terminologische Überlegungen. - Italienisch und Deutsch im Kontakt und Vergleich: Akten des 7. Treffens der Italienischen und österreichischen Linguisten (17-19 October 1996, Innsbruck, Austria). P. Cordin, M. Iliescu, H. Siller-Runggaldier (eds.), Trento: Università di Trento, 399-417.

Streiter O., Ralli N., Ties I., Voltmer L. 2004: BISTRO, the Online Platform for Terminology Management: Structuring Terminology without Entry Structures. - Linguistica Antverpiensia, New Series - Themes in Translation Studies 3, 203-215. 
Verra R. 2005: L'insegnamento trilingue nelle località ladine della Provincia di Bolzano. - International Journal of the Sociology of Language 171, 115-131.

Woelk J. 2000: Von „Advokat“ bis „Zentraldirektion der Autonomien“. Die Südtiroler Rechtssprache aus Sicht eines „,bundesdeutschen“ Juristen. - Rechtslinguistik des Deutschen und Italienischen. D. Veronesi (ed.), Padova: UNIPRESS, 209-222.

Zanola M. T. 2018: Che cos'è la terminologia, Rome: Carocci.

Zanon H. 2001: Spurensuche 1999: Die deutsche Sprache bei Gericht in Südtirol. - Die deutsche Sprache in Südtirol. Einheitssprache und regionale Vielfalt. K. Egger, F. Lanthaler (eds.), Vienna / Bolzano: Folio, $168-186$.

Zweigert K., Kötz H. 1996: Einführung in die Rechtsvergleichung. 3rd ed., Tübingen: Mohr Siebeck.

\section{TERMINOLOGIJOS DARBAS PIETŲ TIROLYJE: NAUJI POŽIŪRIAI, NAUJA TERMINŲ BAZĖ, NAUJAS TURINYS}

Santrauka

Straipsnyje aprašoma teisès terminologijos darbo raida Pietų Tirolyje nuo Antrojo pasaulinio karo laikų iki šių dienų. Pietų Tirolis yra daugiakalbẻ Šiaurès Italijos provincija, kurioje kaip mažumų kalbos yra ịteisintos vokiečių kalba ir ladinų kalba. Daugiausia dėmesio skiriama vokiškos terminijos tvarkybai, atskleidžiami metodų ir požiūrių pokyčiai. Sisteminị, ị standartizavimą orientuotą požiūrị neseniai pakeitẻ labiau aprašomojo pobūdžio metodas, sudarantis sąlygas specialesnei, ị tekstą orientuotai terminologijai. Esmine Eurac Research atliekamų terminologijos srities darbų metodologine ypatybe yra tapęs itališkos ir vokiškos (naudojamos Austrijoje, Vokietijoje, Šveicarijoje) kalbų sistemų lyginimas mikrolygmeniu. Internete pateikiamoje teisès terminijos informacineje sistemoje (http://bistro.eurac.edu/) kiekvienas terminas priskiriamas vienai ar kelioms konkrečioms teisès sistemoms ir taip parodomas sisteminis teisès terminijos pobūdis. Kuriant Pietų Tirolio vokiečių kalbos terminiją, toks sistemiškumas padeda išvengti per didelio vietinès teisès kalbos regioniškumo, nes kai tik galimi priimtini atitikmenys užsienio kalba, terminai gali būti adaptuojami ir vartojami Pietų Tirolyje. Šalims bendradarbiaujant ir prekiaujant, tai gerina tarpvalstybinius Italijos ir vokiškai kalbančių šalių santykius. Siekiant tenkinti tikslinių vartotoju poreikius ir reikalavimus, 2016 m. sistema bistro buvo iš esmès atnaujinta. Dabartinè apima teisines kolokacijas, tobulesnes filtravimo funkcijas, išplėstinị kontekstą, prieigą prie visos bibliografinės informacijos, grịžtamojo ryšio funkciją. Vartotojų pageidavimu įtraukiama naujų sričių, pavyzdžiui, profesinė sveikata ir sauga, o tai kelia nemažų metodologinių iššūkių. Kad terminologijos darbai ir toliau turètų vertę, jie turi būti taikomi prie teisinių, technologinių ir visuomenès pokyčių. Taikomieji metodai, priemonès ir turinys turi atitikti kintančius tikslinių vartotojų grupių poreikius, skatinti terminijos sklaidą.

Gauta 2019-08-19

Elena Chiocchetti

Eurac Research

Institute for Applied Linguistics

Viale Druso 1, I-39100 Bolzano

E-mail elena.chiocchetti@eurac.edu 